\title{
PRILOZI
}

ORHAN JAŠIĆ

\section{OD ZORE DO SUMRAKA}

(Evangelos D. Protopapadakis, From Dawn till Dusk (Bioethical

Insights into the Beginning and the End of Life), Logos Verlag,

Berlin, 2019.)

Danas, možda znatno više neodvojivo je od filozofske negoli prije, vode se mnoge tradicije, budući da se upravo kroz polemike kao i diskusije o brojnim povijesno mišljenje anticipiraju bioetičkim temama. No sama moralno-etički problemi. Na tome bioetika kao znanstvena disciplina tragu, štaviše kantijanski, o unutar praktičke filozofije jest bioetičkim problemima je pisao i terminološki novijeg datuma, mada profesor filozofije sa atinskog se određene pojave bioetičke Univerziteta dr. Evangelos D. naravi detektiraju još u drevno tj. Protopapadakis. Inače profesor antičko doba kada se tek počela Protopapadakis nije nepoznat formirati europska kultura i našemu čitateljstvu budući da civilizacija. Ipak u posljednjih intenzivno istražuje bioetičke teme nekoliko decenija su i te kako dugi niz godina iz filozofskog primjetni „naučni pravci“ koji rakursa, a uredio je i jednu knjigu pokušavaju „odvojiti“ bioetiku od na srpskome jeziku Primenjena njene matične postojbine tj. etike, etika (Novi Sad, Mediteran kako bi ju „premjestili“ Publishing, 2004.). Izuzetno je prvenstveno u polje prirodnih ili aktivan i kao izlagač na naučnim društvenih nauka. konferencijama u regionu.

$S$ druge pak strane, Najnovija knjiga Evangelosa D. razmatranje bioetičkih problema Protopapadakisa iz polja bioetike, 
koju predstavljamo, nosi znakovit naziv Od zore do sumraka (bioetički pogledi o početku i kraju života) - From Dawn till Dusk (Bioethical Insights into the Beginning and the End of Life). Djelo je strukturirano kroz osam poglavlja. Predgovor za knjigu je napisala Stacy Gallin nakon čega slijedi auktorov Uvod a zatim i poglavlja: Pobačaj i čedomorstvo: filozofska pozadina (Abortion and infanticide: The philosophical background), Odbrana pobačaja, protiv prava na život (Defending abortion against the right to life), CRISPR/Cas 9: obećanja i opasnosti gentičkog inžinjeringa (CRISPR/Cas 9: The promises and the perils of genetic engineering), Humano reproduktivno kloniranje $i$ pravo na jedinstveni identitet (Human reproductive cloning and the right to a unique identity), $O$ strahu od smrti: Epikurovo naslijede (On the fear of death: Epicurus' legacy), $O$ racionalnom samoubojstvu: stoici $i$ argument 'otvorenih vrata' (On rational suicide: The Stoics and the 'open door' argument), $O$ aktivnoj $i$ pasivnoj eutanaziji (On active and passive euthanasia), O pravu na umiranje (On the right to die). Nakon toga slijedi vrlo bogata bibliografija koju je auktor koristio tijekom iscrpnog razmatranja navedene tematike, dok je na kraju knjige moguće pronaći iscrpan indeks imena i pojmova.

Iz samog naslova knjige, koji je više negoli zanimljiv i izazovan, evidentno je da je riječ o temi ljudskoga bivstvovanja od najranijeg doba do smrti. U fokusu Protopapadakisovog istraživanja je primarno pozicionirano ljudsko biće, $\mathrm{s}$ tim da se $\mathrm{s}$ vremena na vrijeme u osnovnim crticama osvrće i na neljudska bića tj. životinje. Specifičnost ovoga djela temelji sa na činjenici da auktor kroz historiju filozofije prezentira široki dijapazon različitih bioetičkih problema i ukazuje na njihove etičke konzekvence. Iz toga razloga bi prema auktoru djela bioetika trebala regulirati i čuvati interese te pozicionirati prioritetna etička i pravna načela, čime bi se izvršio moralni utjecaj na konstantni progres ljudske vrste.

Vrijedno je izdvojit da, pored brojnih navedenih (bio)etičkih problema, Evangelos D. Protopapadakis, osobito razviđa pojam smrti na tragu epikurejske filozofske tradicije. Tom prilikom ističe da je smrt zapravo arhetip i 
izvor svih strahova te da je strah od smrti i umiranja jedan od najjačih strahova, a razlozi za pojavu ove vrste straha mogu, kako atenski profesor navodi, biti strah od smrti zbog nezavršenih poslova, potom zbog potomstva, nasljedstva i slično. $\mathrm{Na}$ tragu navedene filozofske škole naglašava i da umiranje kao proces može osim tjelesne boli prouzročiti i mentalnu bol ili patnju. Kada je riječ o umiranju i smrti, Protopapadakis je mišljenja da smrt uopće nije zlo, što izražava ponovno na tragu epikurejske škole, te da je o smrti zbog farmaceutskih studijskih smjerova. odsustva svakog mogućega iskustva, za razliku od boli, patnje, i straha od umiranja, teško pisati.

Teme iz naslova su razmatrane hronološkim redom, a auktor bez obzira što mu engleski jezik nije maternji piše veoma prijemčivim i akademskim stilom. Knjigu je izdala 2019. godine renomirana izdavačka kuća Logos Verlag iz Berlina, a obuhvaća 253 stranice teksta. Ovim štivom se mogu koristiti prilikom izučavanja bioetičkih problema kako nastavnici jednako tako i studenti filozofskih, religioloških, teoloških, medicinskih, zdravstvenih i 